\title{
The Potential of Landfill Mining in Two Inactive Zones of the Bantar Gebang Landfill in Jakarta, Indonesia
}

\author{
Gabriel Andari Kristanto $^{1 *}$, Aldi Jansen ${ }^{1}$, William Koven ${ }^{1}$ \\ ${ }^{1}$ Environmental Engineering Study Program, Department of Civil Engineering, Faculty of Engineering, \\ Universitas Indonesia, Kampus UI Depok, Depok 16424, Indonesia
}

\begin{abstract}
Waste management in Jakarta is currently faced with a shortage of landfill space, and landfill mining could be a solution to this problem. The waste excavated from landfills can be utilized as compost, soil amendment, or RDF (refuse-derived fuel). This study aims to analyze the potential for landfill mining materials from two inactive zones of Jakarta's largest landfill, Bantar Gebang, and using those materials as compost and RDF. It was found that the material excavated from this landfill was dominated by soil-like materials $(33-35 \%)$ and plastic $(26-31 \%)$. The soil-like material had a 47-51\% water content and a 4.42-6.23 C/N ratio, and it did not meet Indonesia's national standard for compost. The materials for RDF had 13-15 MJ/kg calorific values, 48-50\% water and $24-27 \%$ ash contents, and a possibility of high chlorine emission. No RDF standard is currently available in Indonesia, but the materials did not meet the European standard. It is suggested that soil-like materials be used for soil amendment instead of compost; plastic waste and other combustible materials should be separated and dried to fulfill the RDF standard.
\end{abstract}

Keywords: $\quad$ Bantar Gebang; Indonesia; Landfill mining; Waste, Refuse-derived fuel

\section{Introduction}

Indonesia is the fourth most populous country globally, and the population is concentrated in its capital, Jakarta. The city is home to around 10 million people and is a working hub for other big cities close to Jakarta. Jakarta's waste generation can reach approximately 8,000 tons per day, and more than $50 \%$ of this is organic waste (BPS, 2005; BPS, 2017). Despite the massive generation of waste and lack of source separation, the Jakarta waste management system relies heavily on landfills.

When solid waste is disposed of in landfills, aerobic decomposition initially occurs. With compaction and the application of a daily cover, the waste begins to undergo anaerobic decomposition. Due to the lack of oxygen, microorganisms use nitrate and sulfate as electron acceptors. In the acid (hydrolysis) phase, macromolecule hydrolysis, such as that of cellulose and protein, enhances organic acid production and decreases $\mathrm{pH}$ levels. Hydrogen gas is also generated as the degradation of butyric and propionic acids proceeds. In the methanogenic phase, the methanogenic microorganism consumes organic acid and hydrogen gas to generate methane (Themelis and Uloa, 2007; Townsend et al., 2015).

Chen et al. (2020) conducted a study on the stabilization behavior of MSW (Municipal

${ }^{*}$ Corresponding author's email: andari@eng.ui.ac.id; g.andari.kristanto@gmail.com, Tel.:+ 62-21-7863516; fax: +62-21-7863515

doi: 10.14716/ijtech.v11i7.4571 
Solid Waste) with high and low food waste content in landfills (Chen et al., 2020). MSW with high food waste content (HFWC) (more than 40\%) has a significantly higher sugar content (more than 70\%) than low food waste content (LFWC) MSW. This sugar is an easily degradable material.

For HFWC, the rapid degradation stage of MSW occurs in the first three years after the waste is deposited in landfills: about $80 \%$ of the solid waste degrades, $60 \%$ of the landfill gas (LFG) is generated, and $80 \%$ of the compression takes place. Subsequently, a slow degradation stage will occur for the next 20 to 30 years, with around $90 \%$ of the solid mass degrading, $80 \%$ of the LFG being generated, and $90 \%$ of waste stabilization being completed. Finally, the process concludes with post-stabilization, where the solid waste is completely degraded, while LFG generation and waste settlement are negligible (Chen et al., 2020).

Several studies have been conducted on Jakarta's solid waste potential to be used as renewable energy, and landfill mining could be the best solution for waste management problems in Jakarta (Adiandri and Kristanto, 2019; Kristanto and Rachmansyah, 2020). Landfill mining describes the process of excavating previously landfilled waste. The benefits of landfill mining include removing the source of groundwater pollution and valorizing landfill material as RDF (refuse-derived fuel), compost, or daily landfill cover (Prechthai et al., 2008; Jain et al., 2013; Townsend et al., 2015). As the material is reused, the area will be available for new fresh waste and, therefore, the landfill's life will be extended. In addition, the cost of landfill post-closure could be avoided.

Many landfill reclamation projects have been conducted in the United States (US), such as those in Naples, Florida; Edinburg, New York; Frey Farm, Pennsylvania; Wyand ot County, Ohio; Shawano County, Wisconsin; Clovis, California; Pheonix Rio Salado, Arizona; the central disposal system in Iowa; and many others (Townsend et al., 2015). Although landfill reclamation is an old concept in the US, it is very new in Indonesia. This study represents the first study on landfill mining published in Indonesia; hence, it can serve as an example for future research and a model for similar research on landfill mining in Indonesia.

From the point of view of regulations, the Ministry of Public Work in the Republic of Indonesia (MoPW) sets the criteria for landfill mining, and at least one of the criteria must be met before landfill mining can be conducted. Among the criteria are that: (1) the landfill has an impact on the environment; (2) the government cannot find other appropriate areas for landfills; and (3) the landfill handles non-hazardous waste (Indonesia Ministry of Public Works, 2013). The Bantar Gebang landfill certainly met some criteria, as indicated by its groundwater pollution, and the Jakarta Government has not found other areas for landfills yet (Indiyati et al., 2019). Furthermore, the regulation mentions that the soil-like material from landfill mining can be utilized in daily landfill cover, biofilters for leachate treatment, and compost for non-edible crops. At the same time, non-organic material can be used for energy recovery. The remaining unused material can be sent back to the landfill (Indonesia Ministry of Public Works, 2013).

This study aims to identify the potential for the landfilled waste in two inactive zones of the Bantar Gebang landfill to be utilized as RDF, compost, soil amendment, or daily landfill cover in concordance with the needs of Jakarta and regulations set by the Indonesia Ministry of Public Works. This study will compare the testing parameters of excavated landfill material with the Indonesian national standard (SNI) and the international standard (European Commission-Directorate General Environment, 2003) for safe and suitable material utilization. Moreover, some previous studies will be highlighted for comparison and point out the research that could be further conducted to support landfill mining studies and projects in Indonesia. 


\section{Methods}

\subsection{Location of the Study}

The Bantar Gebang landfill, the largest landfill in Indonesia, is managed by Jakarta's government and is located $40 \mathrm{~km}$ from central Jakarta (Figure 1). The Bantar Gebang landfill began operating in August 1989 to handle all MSW from the Jakarta region. It comprises five zones on a 92.41 ha area (Table 1). The total area of the Bantar Gebang landfill, which includes the supporting facilities, is $108 \mathrm{ha}$. When the waste truck arrives at the receiving dock, the weight of the waste is scaled and calculated. Usually, there is more than one unloading point to optimize the process. The waste is subsequently spread and compacted. After one cell is full, the soil covers the waste, and a geomembrane is then applied. Organic waste from the central market of Jakarta is subsequently directed into the composting facility. With a capacity for composting around 1,000 tons per day, the composting facility currently handles around 550 tons per day.

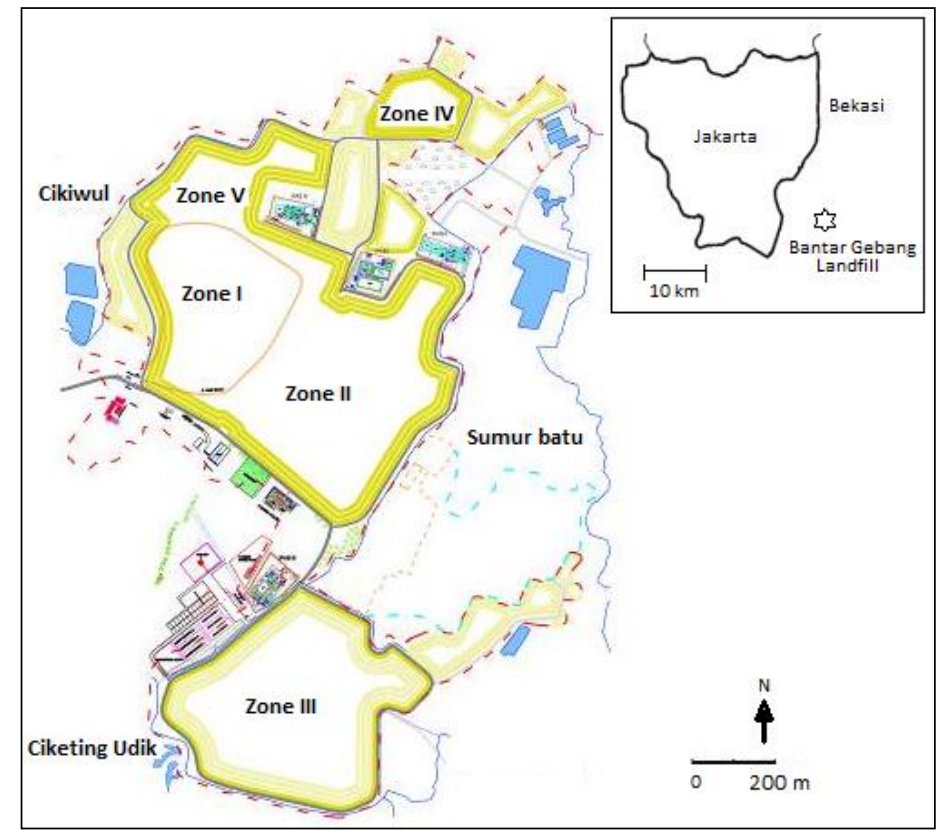

Figure 1 Bantar Gebang landfill layout and location

Table 1 Area and total landfilled waste in Bantar Gebang

\begin{tabular}{ccc}
\hline Zone & $\begin{array}{c}\text { Area } \\
\text { (hectares) }\end{array}$ & Waste landfilled $\left(\mathrm{m}^{3}\right)$ \\
\hline I & 18.30 & $1,786,566.95$ \\
II & 17.70 & $2,744,989.83$ \\
III & 25.41 & $2,787,904.08$ \\
IV & 11.00 & $810,258.21$ \\
V & 9.50 & $803,323.17$ \\
New Zone & 10.50 & - \\
\hline Total Area & 92.41 & $8,933,042.24$ \\
\hline
\end{tabular}

By the time these data were released, waste had filled approximately $97 \%$ of the Bantar Gebang landfill, and the remaining 3\% is planned to handle waste until 2023. The MSW pile is up to 20-30 metres high in Bantar Gebang, with regular landslides during the rainy season (Bahsan et al., 2017). Although the Bantar Gebang landfill has entered the end of its service stage, the Jakarta Government still operates it, since no other landfill is available. 
Bantar Gebang poses many environmental problems besides landslides; for example, in September 2015, a fire consumed around four hectares due to hot weather and methane gas leakage from the MSW (Antara News, 2015). A study in 2019 found the groundwater in the vicinity of the Bantar Gebang landfill to be contaminated by $2 \%$ leachate (Indiyati et al., 2019).

\subsection{Waste Sample}

The waste samples came from Zone IVB and Zone V of the Bantar Gebang landfill. Zone IV covers approximately 11 hectares, and Zone IVB covers half of Zone IV's area (5.5 hectares). Zone IVB was closed in 2006 and has since been inactive, with total landfilled waste reaching $389,999.4 \mathrm{~m}^{3}$. Zone $\mathrm{V}$, which has remained inactive since it was closed in 2003, takes up approximately 9.5 hectares, with total landfilled waste reaching 803,323.17 $\mathrm{m}^{3}$. Among the other zones in Bantar Gebang, only Zone IVB and Zone V were closed and could be mined.

The waste pile on the landfill reached $15 \mathrm{~m}$ at Zone IVB and $20 \mathrm{~m}$ at Zone V, with $30^{\circ}$ inclinations at both zones. Therefore, proper and safe access to the sample required careful consideration. Before the sample was collected, the excavator dug $2 \mathrm{~m}$ deep into the waste to remove the top cover soil and vegetation. At every sampling point, $100 \mathrm{~kg}$ of samples were collected. Three sampling points and a duplicate were selected for each zone.

\subsection{Soil-Like Material Analysis}

An open windrow system composted the soil-like material. The open windrow system was selected because it can handle a larger amount of material and is relatively low-cost compared to other composting techniques (US EPA, 2016; Shukor et al., 2018). Selected soil-like materials were placed in the $1 \mathrm{~m}^{3}$ container, covered with a plastic sheet, passively aerated, and mixed every two days. The temperatures were measured every day, while the carbon-to-nitrogen ratios were measured once a week. The measurement of organic carbon was performed via titrimetric methods using $\mathrm{KMnO}_{4}$ according to Indonesian national standard SNI 19-7030-2004 (BSN, 2004) and reported as a percentage (\%). The total Kjeldahl nitrogen $(\mathrm{N})$ measurement was performed using a spectrophotometer (DR 2000 Hach) and reported as a percentage (\%).

\subsection{Physical and Chemical Analysis}

Table 2 presents the standard methods applied in this study to perform physical and chemical analyses of the waste. The waste's density was measured by placing approximately $100 \mathrm{~kg}$ of the waste in a box and then dropping it three times from a $20 \mathrm{~cm}$ height. The waste's composition was analyzed based on Indonesian national standard SNI 19-3964-1994 (BSN, 1994). Materials for particle size analysis were divided into two groups: commingled waste samples and organic waste samples. The purpose of the organic waste particle size analysis was to determine the organic waste's suitability as compost or soil amendment. For commingled waste analysis, two screens with different diameters (40 $\mathrm{mm}$ and $8 \mathrm{~mm}$ ) were used, and for organic waste analysis, eight screens with different diameters $\left(1^{\prime}, 0.5^{\prime}, 0.375^{\prime}\right.$, and $4-40^{\prime}$ screens for fine aggregate) were used.

\subsection{Data Analysis}

The data were analyzed and compared to an applied standard for RDF and compost. 
Table 2 Laboratory standard and analysis

\begin{tabular}{ll}
\hline \multicolumn{1}{c}{ Parameter } & \multicolumn{1}{c}{ Method } \\
\hline Waste composition & SNI 19-3964-1994 \\
Water content & SNI 03-1971-1990 \\
Volatile content & Standard Method 2540 E \\
Ultimate analysis of C and H & ASTM E777-08 \\
Ultimate analysis of N & ASTM D5373-14 \\
Ultimate analysis of O & ASTM D 3176-15 \\
Caloric Value & ASTM D5865 \\
Carbon & SNI 19-7030-2004 \\
Total N & Kjeldahl Nitrogen \\
Calorific value & Parr 6200 bomb calorimeter \\
\hline
\end{tabular}

\section{Results and Discussion}

3.1. Waste Composition, Density, and Water Content Analysis

Table 3 shows the composition, bulk density, and water content of the excavated landfill materials. The result indicates that soil-like material and total plastics (dense plastic and plastic film) dominated both zones' compositions.

Table 3 Waste composition, water content, and bulk density of excavated materials

\begin{tabular}{lrr}
\hline \multicolumn{1}{c}{ Waste Composition } & \multicolumn{1}{c}{$\begin{array}{c}\text { Zone IVB* } \\
\text { Weight (\%) }\end{array}$} & \multicolumn{1}{c}{$\begin{array}{c}\text { Zone } \mathrm{V}^{* *} \\
\text { Weight (\%) }\end{array}$} \\
\hline Soil-like material (\%w) & $33.15 \pm 1.24$ & $35.54 \pm 2.55$ \\
Plastic film (\%w) & $26.14 \pm 1.09$ & $30.12 \pm 4.00$ \\
Dense plastic (\%w) & $1.88 \pm 0.13$ & $1.46 \pm 0.52$ \\
Woods (\%w) & $14.28 \pm 1.37$ & $15.29 \pm 1.58$ \\
Fabric/textile (\%w) & $13.89 \pm 1.53$ & $8.38 \pm 6.24$ \\
Rubber/leather (\%w) & $2.13 \pm 0.95$ & $1.40 \pm 0.43$ \\
Styrofoam (\%w) & $1.24 \pm 0.33$ & $0.67 \pm 0.50$ \\
Metals (\%w) & $0.48 \pm 0.21$ & $0.78 \pm 0.23$ \\
Porcelain (\%w) & $0.40 \pm 0.17$ & $0.60 \pm 0.48$ \\
Paper/cardboard (\%w) & $0.99 \pm 0.37$ & $2.19 \pm 0.21$ \\
Bones (\%w) & $0.45 \pm 0.18$ & $0.13 \pm 0.04$ \\
Glass (\%w) & $1.00 \pm 0.08$ & $0.85 \pm 0.34$ \\
Construction waste (\%w) & $2.22 \pm 0.27$ & $0.45 \pm 0.34$ \\
Specific hygiene products & $1.16 \pm 0.22$ & $0.42 \pm 0.73$ \\
(\%w) & $0.00 \pm 0.01$ & $0.03 \pm 0.03$ \\
E-waste (\%w) & $0.54 \pm 0.72$ & $1.68 \pm 0.83$ \\
Rocks (\%w) & $0.05 \pm 0.04$ & - \\
Hazardous waste (\%w) & 469.73 & 435.43 \\
Bulk density (kg/m $\left.{ }^{3}\right)$ & 48.60 & 49.34 \\
Water content (\%) & &
\end{tabular}

Note: *Closed in 2006

${ }^{* *}$ Closed in 2003

The total plastic content varied from $28.02 \%$ to $31.58 \%$, and the soil-like material comprised $33.15 \%$ and $35.54 \%$ in Zone IVB and Zone V, respectively. Soil-like material consists of organic waste that does not easily degrade, soil from the daily cover, and other material that is too small to be separated from the dominant organic waste content. During the landfill operation, Jakarta's waste was dominated by organic waste, which accounted for $65.05 \%$ of the total waste; this number is almost twice that of soil-like material (BPS, 
2005). According to Chen et al. (2020), HFWC MSW, such as the MSW in Jakarta, is rich in readily biodegradable material; the mass of such MSW could be $80 \%$ consumed in the first three years (Chen et al., 2020). However, in this study, organic waste, represented by soillike material, had a 50\% mass reduction. Moreover, since the soil-like material was organic, it was difficult to separate it from the daily soil cover and other tiny materials.

A previous study at the Nonthaburi dumping site found that soil-like material (27$57 \%$ ) and plastic (25-45\%) dominated the composition of the excavated material (Chiemchaisri et al., 2010). At the same dumping site, Prechthai et al. (2008) also discovered that plastic (35-51\%) and fine particles (19-30\%) that consisted of soil and other tiny materials were the dominant components in the excavated material (Prechthai et al., 2008).

A similar trend was also recorded by Kaartinen et al. (2013) at the Kuopio landfill in Finland. Their study found that plastic and fine particles smaller than $20 \mathrm{~mm}$ constituted a dominant fraction of the total waste (Kaartinen et al., 2013). As a European Union member, Finland must either treat organic waste before it enters landfills or deposits it in bioreactor landfills. Hence, organic waste was not a dominant fraction of the Kuopio landfill. By comparing the plastic content in excavated landfill material with older landfills (those landfilled between 1987 and 2003), further analysis has shown that the trend of plastic usage has increased (Kaartinen et al., 2013). Supporting this claim, Rotheut and Quicker (2017) found that the excavated waste from German landfills used in 1995-1998, 19911995, and 1995-2002 had a plastic content of $19.7 \%, 38.9 \%$, and $42.6 \%$, respectively (Rotheut and Quicker, 2017). The increasing plastic content in Jakarta's waste from 2000 to 2014 also supports this claim (BPS, 2005; BPS, 2017).

As for wood, even though it is categorized as organic waste, the higher the lignin content of a material, the more difficult it is to degrade. Degradation of this recalcitrant degradable material will thus happen in the slow degradation stage, resulting in 20 to 30 years of landfilled material (Chen et al., 2020). As for the increase of the wood composition percentage, it was due to the significant loss of organic material, which caused the overall mass to decrease; accordingly, the proportions of some types of waste composition increased, as happened with textile and plastic (Prechthai et al., 2008). Meanwhile, the paper portion of the excavated waste decreased significantly compared to paper portion of fresh waste from Jakarta. This is because leachate and other waste contaminate the paper in the landfill. So the longer the paper in the landfill, the more it cannot be separated from its contaminant. This trend was also encountered in the five to ten years of landfill waste, which can be compared to two years of waste at the dumpsite (Chiemchaisri et al., 2010).

In this study, the acquired metal composition was $0.48 \%$ and $0.78 \%$ in Zone IVB and Zone $\mathrm{V}$, respectively. Metals have high economic value and sell quickly among waste scavengers; hence, the amount of metal in landfills is low. Although there is no formal waste separation in Jakarta, the informal sector has become a large business that includes waste pickers who collect waste from household garbage bins and extends to large waste collectors who surround the Bantar Gebang landfill (Kristanto et al., 2015). Studies also report a low metal content in excavated landfill material (around 3-4\%), but it is mostly of non-marketable quality (Jain et al., 2013; Kaartinen et al., 2013). Kaartinen et al. (2013) also highlighted that the use of a mechanical process would render less metal content than manual separation in excavated landfill material. However, the mechanically processed metals were presented in a cleaner state than those sorted manually (Kaartinen et al., 2013).

The excavated landfill material had a waste density of $469.73 \mathrm{~kg} / \mathrm{m}^{3}$ in Zone IVB and $435.43 \mathrm{~kg} / \mathrm{m}^{3}$ in Zone V. The water content of Zone IVB and Zone V was $48.60 \%$ and $49.34 \%$, respectively. Water content was found to contribute positively to bulk density and 
would increase in proportion to the excavated material's depth (Prechthai et al., 2008; Kaartinen et al., 2013). The waste's composition also affects the bulk density; as Chiemchaisri et al. (2010) point out, higher soil-like material levels lead to higher bulk density. However, in contrast with this study, Chiemchaisri et al. (2010) and Prechthai et al. (2008) recorded a maximum bulk density of around $400 \mathrm{~kg} / \mathrm{m}^{3}$ with a similar water content was about $50 \%$. An explanation for this might be that the wood fraction in this study was three times the previous studies' content. The degree of compaction and soil use as daily cover could also contribute to the high bulk density (Prechthai et al., 2008; Kaartinen et al., 2013).

The highest water content in the excavated material was found in paper, wood, and Styrofoam (each with more than $60 \%$ water content). By comparison, the average water content for dominant materials, such as soil-like material and plastic, was $49 \%$ and $48.8 \%$, respectively. This contradicts a previous study that found that ten-year-old waste had low water content in soil-like material, plastic, and wood (water content $\leq 10 \%$ ) (Chiemchaisri et al., 2010). This difference could be due to precipitation: Jakarta has an annual precipitation rate of $1.950 \mathrm{~mm}$ (BPS, 2014), while in Bangkok, the annual precipitation rate is $1,450 \mathrm{~mm}$ (Weatherbase, 2017). Other causes might include the characteristics of the initial waste that enters the landfill and the daily landfill operations that cause the water to remain with the waste. The materials' high water content will contribute to their utilization as RDF, since high water content leads to low calorific value.

\subsection{Particle Size Analysis}

The particle sizes of the excavated materials are presented in Table 4. Around $64.19 \%$ of the material had a particle size greater than $40 \mathrm{~mm}$, and the material mainly consisted of plastic, rubber, and wood. Meanwhile, soil-like material was dominant in material with a particle size of less than $40 \mathrm{~mm}$. A previous study at the Nonthaburi dumping site in Thailand also reported a similar particle size distribution (Prechthai et al., 2008). It found that around $69 \%$ of the excavated waste was larger than $50 \mathrm{~mm}$, and the material consisted of plastic, wood, and textile. At the same time, the material with a particle size of less than $50 \mathrm{~mm}$ was dominated by soil.

Another study found a similar result with particle sizes greater than $40 \mathrm{~mm}$, which included around $47-51 \%$ of the excavated materials (Kaartinen et al., 2013). However, particle sizes of less than $20 \mathrm{~mm}$ composed $43-47 \%$ of the excavated material, which is almost the same percentage for particle sizes larger than $40 \mathrm{~mm}$. This similarity can be explained by the source separation process pervasive in developed European countries, such as Finland. Source separation separates the refuse, which usually has a tiny particle size, from other waste, which still has economic value and, generally, a greater particle size. For countries with no source separation, such as Indonesia, aside from the large volume of waste sent into landfills, the material's particle size also varies, which lowers the number of tiny particles to landfill.

Table 4 Excavated waste sample particle size

\begin{tabular}{ccc}
\hline \multirow{2}{*}{ Particle size } & \multicolumn{2}{c}{$\%$ Weight } \\
\cline { 2 - 3 } & Zone IV B & Zone V \\
\hline$>40 \mathrm{~mm}$ & $59.83 \pm 1.04$ & $68.55 \pm 0.97$ \\
$8-40 \mathrm{~mm}$ & $37.17 \pm 1.46$ & $30.00 \pm 1.30$ \\
$<8 \mathrm{~mm}$ & $3.00 \pm 0.66$ & $1.50 \pm 0.35$ \\
\hline
\end{tabular}


Table 5 Comparison of soil-like material to compost standard

\begin{tabular}{lrrr}
\hline \multicolumn{1}{c}{ Parameter } & Zone IVB & \multicolumn{1}{c}{ Zone V } & SNI 19-7030-2004 \\
\hline Water content (\%) & $51.10 \%$ & $47 \%$ & $\leq 50 \%$ \\
Particle size & $85 \% *$ & $85 \% *$ & $0.55-25 \mathrm{~mm}$ \\
Organic content (\%) & 75.22 & 73.17 & $27-58 \%$ \\
Nitrogen (\%) & 1.09 & 0.95 & $>0.4 \%$ \\
Carbon (\%) & 42.46 & 45.91 & $9.8-32 \%$ \\
C/N ratio & $4.42-6.23$ & $4.42-6.23$ & $10-20$ \\
\hline
\end{tabular}

Note: * Only $85 \%$ meets the particle size standard

\subsection{Soil-Like Material and its Utilization Potential}

Around 33-35\% of the excavated landfill material was soil-like material. Some studies have utilized this material as daily landfill cover, and some use it as compost (Prechthai et al., 2008; Chiemchaisri et al., 2010; Jain et al., 2013; Masi et al., 2014). In this study, as this soil-like material was intended as compost, stability, and other parameters were assessed relative to Indonesia standard SNI 19-7030-2004 (BSN, 2004).

The purpose of composting is to decompose biomass fully. In this study, the sample was composted, and no change in temperature was recorded in the models. The constant temperature during windrow composting was similar to ambient temperature $\left(27^{\circ} \mathrm{C}\right)$, indicating no microorganism activity that generated heat was present. The constant $\mathrm{C} / \mathrm{N}$ ratio observed suggested that these food supply substances were no longer available. Although the soil-like material had a dominant composition in the excavated landfill waste and the material had reached a stable state, the soil-like material was not suitable for use as compost, as it failed some compost standards requirements. Masi et al. (2014) studied the usage of fine particles $(<4 \mathrm{~mm})$ and concluded that the material is used in bio-soils for remediation, daily landfill cover, and compost for non-edible crops. For comparison, their study's material had 5.2\% total organic compound (TOC) and a pH of 6.7, while the Indonesia standard calls for TOC $\geq 9.8$ and $\mathrm{pH} \geq 6.8$. Furthermore, the total heavy metal and leaching potential were lower than the US EPA's limit, but the material harmed Vicia faba (Masi et al., 2014). Therefore, the compost was only suitable for non-edible crops.

A study in Thailand also reported that the fine material $(<25 \mathrm{~mm})$ from the dumpsite was suitable for being compost for the only non-edible crop, as the $\mathrm{Cu}$ concentration was higher than Thailand's compost standard (Prechthai et al., 2008).

\subsection{RDF Potential}

In addition to the calorific value measurement taken with a bomb calorimeter, various models were also applied to calculate the excavated waste's calorific value. The calorific value errors were calculated via Dulong mode as $4.6 \%$ and $0.6 \%$ for Zone IVB and Zone V, respectively. The percentage of errors from the Institute of Gas Technology, which considered ash content, was $0.3 \%$ and $4.8 \%$ for Zone IVB and Zone V, respectively. However, the models by Tillman and Lloyd-Davenport bear more than $10 \%$ error because they are developed for wood (Tillman) and fossil fuels (Llyod-Davenport) (Buckley and Domalski, 1998).

Although the calorific value of Bantar Gebang waste met the European standard, it was considered low compared to values in previous studies. The excavated material previously studied exhibited twice the calorific value of the material in this study (Prechthai et al., 2008; Chiemchaisri et al., 2010; Kaartinen et al., 2013; Rotheut and Quicker, 2017). The low calorific value in this study might be due to the high water content and mixed materials.

Chiemchaisri et al. (2010) studied the potential for plastic waste from excavated material to be used as RDF. They found that, although plastic (especially plastic bags) has a 
high calorific value (27.5-38.5 MJ/kg), the material also possesses a high content of ash (27\%), chlorine (0.65-1.26\%), and sulfur (0.22-0.36\%) (Chiemchaisri et al., 2010). The European standards for chlorine and sulfur in RDF are $0.4 \%$ and $0.5 \%$ (European Commission-Directorate General Environment, 2003). Furthermore, the study found that for plastic in bags to be used as RDF or as a bulking agent, plastic waste's maximum composition could be $55.56 \%$. As a result, the ash, chlorine, and sulfur content could be reduced to $10.3 \%, 0.44 \%$, and $0.14 \%$, respectively.

Another study by Kaartinen et al. (2013) analyzed the excavated material and concluded that around $40-45 \%$ of the materials-which were plastic, paper/cardboard, textile, and wood-were suitable for energy recovery (Kaartinen et al., 2013). These materials could reach $22 \mathrm{MJ} / \mathrm{kg}$ of net calorific value in dry conditions. By comparison, in this study, materials such as plastic, wood, paper/cardboard, and textile composed around $55 \%$ of the excavated waste.

The carbon, hydrogen, and nitrogen content were in the study's range by Roheut and Quicker (2017). Pasek et al. (2013) conducted a study on fresh waste in Indonesia's big city and found that the sulfur and chlorine contents are around $0.195 \%$ and $0.09 \%$, respectively. The content is still in the study range by Roheut and Quicker (2017) (Pasek et al., 2013; Rotheut and Quicker, 2017).

Table 6 RDF potential analysis and ultimate analysis of excavated waste

\begin{tabular}{|c|c|c|c|c|c|c|}
\hline Parameter & $\begin{array}{l}\text { Zone } \\
\text { IVB }\end{array}$ & Zone V & $\begin{array}{l}\text { Rotheut \& } \\
\text { Quicker } \\
\text { (2017) } \\
\end{array}$ & $\begin{array}{l}\text { The United } \\
\text { Kingdom* }\end{array}$ & $\begin{array}{l}\text { Italy } \\
\text { Standard }\end{array}$ & $\begin{array}{l}\text { European } \\
\text { Standard }\end{array}$ \\
\hline \multicolumn{7}{|l|}{ RDF potential analysis } \\
\hline Calorific Value (MJ/kg) & 15.14 & 13.72 & $19.6-35$ & 18.7 & 15 & 15 \\
\hline Water Content (\%w) & 48.60 & 49.34 & $9.2-25$ & $7-28$ & $<25$ & - \\
\hline Ash Content (\%w) & 24.78 & 26.83 & $10-25$ & 12 & 20 & 5 \\
\hline Volatile Content (\%w) & 75.22 & 73.17 & $65.9-84$ & 68 & - & - \\
\hline Chlorine (\%w) & - & - & $0.5-2$ & $0.3-1.2$ & 0.9 & 0.5 \\
\hline Sulfur $(\% w)$ & - & - & $0.1-0.5$ & $0.1-0.5$ & 0.6 & 0.4 \\
\hline \multicolumn{7}{|l|}{ Ultimate analysis } \\
\hline Carbon $(\% \mathrm{w})$ & 42.46 & 45.91 & $27.8-55.1$ & - & - & - \\
\hline Hydrogen $(\% w)$ & 4.50 & 4.19 & $4.0-7.7$ & - & - & - \\
\hline Oxygen (\%w) & 42.90 & 42.40 & - & - & - & - \\
\hline Nitrogen $(\% w)$ & 1.09 & 0.95 & $0.6-1.9$ & - & - & - \\
\hline Dulong (MJ/kg) & 14.44 & 15.23 & - & - & - & - \\
\hline Tillman (MJ/kg) & 16.89 & 18.39 & - & - & - & - \\
\hline $\begin{array}{l}\text { Lloyd \& Davenport } \\
\text { (MJ/kg) }\end{array}$ & 16.76 & 17.68 & - & - & - & - \\
\hline Boie (MJ/kg) & 15.48 & 16.38 & - & - & - & - \\
\hline $\begin{array}{l}\text { The Institute of Gas } \\
\text { Technology (MJ/kg) }\end{array}$ & 15.09 & 15.87 & - & - & - & - \\
\hline
\end{tabular}

Note: *Typical RDF characteristics from the United Kingdom

A study by Rotheut and Quicker (2017) that included an analysis of pollutant concentrations in raw gases and emissions created by the incineration of landfill mining materials concluded that there was no significant change in $\mathrm{CO}, \mathrm{NO}_{\mathrm{x}}$, and $\mathrm{SO}_{2}$ concentrations compared to those produced by the normal incineration of municipal and commercial waste in Hannover, Germany. However, there was a significant change in the concentration of the pollutant hydrogen chloride $(\mathrm{HCl})$ in raw gases produced by landfill mining materials. 
$\mathrm{HCl}$ concentration was normalized if the excavated materials were mixed with MSW (Rotheut and Quicker, 2017). The emissions from landfill mining materials in the study by Rotheut and Quicker (2017) also met all emission standards required by the Indonesian Ministry of Environment and Forestry, except in the case of $\mathrm{HCl}$. These regulations set a 10 $\mathrm{mg} / \mathrm{Nm}^{3}$ limit for $\mathrm{HCl}$, while the emissions from excavated waste material in the study by Rotheut and Quicker (2017) reached $20 \mathrm{mg} / \mathrm{Nm}^{3}$. But these emissions could meet Indonesia's regulations if the excavated waste was mixed with green MSW (Indonesia Ministry of Environment and Forestry, 2016; Rotheut and Quicker, 2017).

One lesson that can be learned from previous studies is that to enhance RDF production's potential, and the excavated waste needs to be separated from the noncombustible waste and dried up to reduce its water content. In this study, the materials with high potential for RDF conversions, such as plastic, wood, textile, and paper/cardboard, were among the materials with the highest water content (50-65\%). Furthermore, to address the ash content in the excavated waste, a bulking agent or fresh MSW could be added to the excavated waste (Chiemchaisri et al., 2010; Rotheut and Quicker, 2017). The added substances will also help reduce the chlorine content in the excavated waste or in the incineration emissions, as the plastic waste in Indonesia has $3.82 \%$ chlorine content (Pasek et al., 2013).

\section{Conclusions}

Landfill mining could be a solution to the problems that are currently faced by the Bantar Gebang landfill, such as the lack of landfill area in the vicinity of Jakarta and the groundwater pollution in the region. Moreover, landfill mining creates some added value by recovering excavated landfill materials, such as compost, daily landfill cover, and RDF.

The landfill material mined was dominated by soil-like material (33.15-35.54\%) and plastic (26.214-30.12\%). The soil-like material was stable but did not meet the basic standard for compost in Indonesia. A solution to this problem is to mix the soil-like material with other materials with a high potential for compost, such as organic waste from fresh MSW. The compost produced will only be suitable for non-edible crops.

The landfill material mined was also not suitable for RDF utilization since it has a low calorific value (maximum $15.14 \mathrm{MJ} / \mathrm{kg}$ ), high water content (48-50\%), high ash content (24-27\%), and a potential for high $\mathrm{HCl}$ emission. It is recommended that the materials suitable for RDF (such as plastic, wood, textile, and paper) should be separated and dried up since these materials have high water content (50-65\%). Bulking agents or green waste can be added to reduce the ash content and chlorine content. It is suggested that soil-like materials be used for soil amendment instead of compost, while plastic wastes and other combustible materials should be separated and dried to fulfill the RDF standard.

\section{Acknowledgements}

This research was supported by Universitas Indonesia Grant No. 1953/UN2.R3.1/HKP.05.00/2019. The authors would like to thank anonymous reviewers for their constructive comments, which significantly improved the final version of this paper.

\section{References}

Adiandri, F.M., Kristanto, G.A., 2019. Potential Commercial Waste in Jakarta as a Renewable Source of Energy. Journal of Physics: Conference Series, Volume 1387, 012147 
Antara News, 2015. Kebakaran TPST Bantargebang meluas (Fire at Bantar Gebang Landfill Escalates). Available Online at https://www.antaranews.com/berita/517881/ kebakaran-tpst-bantargebang-meluas, Accessed on October 7, 2017

Bahsan, E., Andari, G.S.B., Pramiarsih, S., Latief, S., 2017. Geotechnical Characteristics of Bantargebang Solid Landfill Waste using a Laboratory Test on Artificial Waste Samples and a Field Test. International Journal of Technology, Volume 8(6), pp. 1012-1020

Buckley, T.J., Domalski, E.S., 1988. Evaluation of Data in Higher Heating Values and Elemental Analysis for Refuse-Derived Fuels. National Waste Processing Conference, Volume12, pp. 77-84

Chen, Y.M., Xu, W.J., Ling, D.S., Zhan, L.T., Gao, W., 2020. A Degradation-Consolidation Model for the Stabilization Behavior of Landfilled Municipal Solid Waste. Computers and Geotechnics, Volume 118, 103341

Chiemchaisri, C., Charnnok, B., Visvanathan, C., 2010. Recovery of Plastic Wastes from Dumpsite as Refuse-Derived Fuel and its Utilization in Small Gasification System. Bioresource Technology, Volume 101(5), pp. 1522-1527

DKI Jakarta Bureau of Statistics/Badan Pusat Statistik (BPS) DKI Jakarta, 2005. Jakarta dalam Angka 2004 (Jakarta in Figures 2004), BPS DKI Jakarta, Indonesia

DKI Jakarta Bureau of Statistics/Badan Pusat Statistik (BPS) DKI Jakarta, 2014. Jakarta dalam Angka 2013 (Jakarta in Figures 2013), BPS DKI Jakarta, Indonesia

DKI Jakarta Bureau of Statistics/Badan Pusat Statistik (BPS) DKI Jakarta, 2017. Jakarta dalam Angka 2016 (Jakarta in Figures 2016), BPS DKI Jakarta, Indonesia

European Commission-Directorate General Environment, 2003. Refuse Derived Fuel, Current Practice, and Perspectives: Quality Standards for Solid Recovered Fuel. European Commission-Directorate General Environment, Brussels, Belgium

Indiyati, E.R.P., Satrio, S., Prasetio, R., 2019. Major Ions for Tracing Leachate Migration within Shallow Groundwater in the Vicinity of Municipal Landfill in Bantar Gebang Bekasi. Indonesian Journal of Chemistry, Volume 19(1), pp. 19-29

Indonesia Ministry of Public Works/Kementerian Pekerjaan Umum Republik Indonesia. 2013. Peraturan Menteri Pekerjaan Umum Republik Indonesia No 03/PRT/M/2013 tentang penyelenggaraan prasarana dan sarana persampahan dalam penanganan sampah rumah tangga dan sampah sejenis sampah rumah tangga (Regulation of Ministry of Public Work Republic of Indonesia 03/PRT/M/2013 regarding the implementation of municipal solid waste facilities and infrastructures), Kementerian Pekerjaan Umum Republik Indonesia, Jakarta, Indonesia

Jain, P., Townsend, T.G., Johnson, P., 2013. Case Study of Landfill Reclamation at a Florida Landfill Site. Waste Management, Volume 33(1), pp. 109-116

Kaartinen, T., Sormunen, K., Rintala, J., 2013. Case Study on Sampling, Processing, and Characterization of Landfilled Municipal Solid Waste in the View of Landfill Mining. Journal of Cleaner Production, Volume 55, pp. 56-66

Kristanto, G.A., Gusniani, I., Ratna, A., 2015. The Performance of Municipal Solid Waste Recycling Program in Depok, Indonesia. International Journal of Technology, Volume 6(2), pp. 264-272

Kristanto, GA., Rachmansyah, E., 2020. The Application of Refuse Derived Fuel (RDF) from Commercial Solid Wastes to Reduce $\mathrm{CO}_{2}$ Emissions in the Cement Industry: $\mathrm{A}$ Preliminary Study. In: IOP Conf. Series: Earth and Environmental Science, Volume 423, 012014

Masi, S., Caniani, D., Grieco, E., Lioi, D.S., Mancini, I.M., 2014. Assessment of the Possible Reuse of MSW Coming from Landfill Mining of Old Open Dumpsite. Waste Management, Volume 34(3), pp. 702-710 
National Standardization Agency of Indonesia/Badan Standarisasi Nasional (BSN), 1994. SNI 19-3964-1994 Metode Pengambilan dan Pengukuran Contoh Timbulan dan Komposisi Sampah Perkotaan (Method of Sampling and Testing for Domestic Solid Waste Sample and Composition), Badan Standarisasi Nasional, Jakarta

National Standardization Agency of Indonesia/ Badan Standarisasi Nasional (BSN), 1994. SNI 19-7030-2004 Spesifikasi Kompos Dari Sampah Organik Domestic (Specification of Compost from Organic Domestic Waste), Badan Standarisasi Nasional, Jakarta

Pasek, A.D., Gultom, K.W., Suwono, A., 2013. Feasibility of Recovering Energy from Municipal Solid Waste to Generate Electricity. Journal of Engineering and Technological Sciences, Volume 45(3), pp. 241-256

Prechthai, T., Padmasri, M., Visvanathan, C., 2008. Quality Assessment of Mined MSW from an Open Dumpsite for Recycling Potential. Resources, Conservation, and Recycling, Volume 53(1-2), pp. 70-78

Rotheut, M., Quicker, P., 2017. Energetic Utilization of Refuse Derived Fuels from Landfill Mining. Waste Management, Volume 62, pp. 101-117

Shukor, J.A, Omar, M.F., Kasim, M.M., Jamaluddin, M.H., Naim, M.A., 2018. Assessment of Composting Technologies for Organic Waste Management. International Journal of Technology, Volume 9(8), pp. 1579-1587

Themelis, N.J., Ulloa, P.A., 2007. Methane Generation in Landfills. Renewable Energy, Volume 32(7), pp. 1243-1257

Townsend, T.G., Powell, J., Jain, P., Xu, Q., Tolaymat, T., Reinhart, D., 2015. Sustainable Practices for Landfill Design and Operation. Springer: New York, USA, pp. 454-471

The United States Environmental Protection Agency (US EPA), 2016. Sustainable Management of Food. Available Online at https://www.epa.gov/sustainablemanagement-food/types-composting-and-understanding-process\#aeratedturned, Accessed on December 3, 2020

Weatherbase, 2017. Bangkok, Thailand. Available Online at http://www.weatherbase.com /weather/weather.php3?s=055484, Accessed on November 3, 2017 